lain "sikapkerja keras dan produktifitas kerja". Sikap kerja keras dan berusaha untuk merubah nasib, rajin dan sungguh-sungguh dalam melakukan pekerjaan merupakan anjuran dan kewajiban bagi insan yang beragama. Manusia sebagai insan individual dan sosial selalu mempunyai keinginan untuk meningkatkan kemajuan serta taraf hidupnya.

\section{METODE PENELITIAN}

Metode penelitian yang digunakan dalam penelitian ini adalah metode kuantitatif dengan pendekatan empiris karena gejala yang akan diteliti sudah ada secara wajar dan tidak perlu dilakukan eksperimen. data-data yang akan diteliti baik variabel bebas (x) Hubungan peran kepala sekolah sebagai konselor maupun variable terikat (y) Etos kerja guru.

Populasi dalam penelitian ini adalah seluruh guru di SMPN 6 Mataram tahun pelajaran 2017/2018 yang berjumlah 50 orang. instrumen yang dipergunakan adalah berupa instrument angket dengan menggunakan skala Likert.

Angket tersebut terdiri dari 25 item pernyataan masing-masing variabel dengan 4 alternatif jawaban yaitu: jawaban "a" (selalu) diberi skor 4, jawaban "b" (sering) diberi skor 3, jawaban "c" (kadang-kadang) diberi skor 2, dan "d" tidak pernah diberi skor 1 ( Sugiyono, 2014: 107).

\section{HASIL PENELITIAN}

Data yang diperoleh dalam penelitian ini adalah data hasil angket dari Kepala Sekolah Sebagai Konselor Dengan Etos Kerja Guru di SMPN 6 MATARAM.

Berdasarkan hasil analisis datanya, diketahui nilai rhitung sebesar 0,606. Selanjutnya, nilai tersebut dikonsultasikan dengan nilai $\mathrm{r}_{\text {tabel }}$ product moment pada taraf signifikansi $5 \%$ dengan $\mathrm{N}=50$, maka diperoleh nilai $\mathrm{r}_{\text {tabel }}$ product moment sebesar 0,279 . Kenyataan tersebut, menunjukkan bahwa nilai $\mathrm{r}_{\text {hitung }}$ product moment lebih besar dari nilai $\mathrm{r}_{\text {tabel }}$ product moment atau $0,510>0,279$. Dengan demikian, hasil analisis data dalam penelitian ini dinyatakan signifikan. Dan dengan demikian, hipotesis nihil $\left(\mathrm{H}_{0}\right)$ ditolak, sedangkan hipotesis alternatif (Ha) diterima.

Berdasarkan hasil pengujian signifikansi di atas yang menyatakan bahwa nilai $r_{\text {hitung }}$ yang diperoleh sebesar 0,510 yang dikonsultasikan dengan nilai $r_{\text {tabel }}$ sebesar 0,279 pada taraf signifikan 5\%. Hal tersebut menunjukkan bahwa nilai $r_{\text {hitung }}>\mathrm{r}_{\text {tabel}}$, yang berarti kedua variable tersebut memiliki hubungan. Maka kesimpulan yang diperoleh dalam penelitian ini adalah; 'Ada Hubungan Peran Kepala Sekolah Sebagai Konselor dengan Etos Kerja Guru di SMPN 6 Mataram Tahun Pelajaran 2017/2018', yang tergolong dalam kategori sedang. Hal ini sesuai dengan pedoman interpretasi product moment (Sugiyono,2014: 184).

\section{PEMBAHASAN}

Dari hasil penelitian tentang Peran Kepala Sekolah Sebagai Konselor Dengan Etos Kerja guru di SMPN 6 Mataram tergolong dalam kategori sedang. Namun ada dampak positif dari beberapa indikator yang mendukung penelitian ini sehingga memiliki hubungan yang signifikan dari dua variable yaitu hubungan peran kepala sekolah sebagai konselor sebagai variabel $(\mathrm{X})$ dan etos kerja guru sebagai variabel (Y). Jadi peneliti dapat menyimpulkan bahwa peran kepala sekolah sebagai konselor menjadi factor terpenting dalam proses peningkatan etos kerja guru. 
Dari hasil nilai skor angket, dimana hasilnya menunjukkan bahwa etos kerja guru dapat meningkat dengan adanya peran kepala sekolah sebagai konselor, dapat dari kepala sekolah mengadakan rapat penyusunan program pembelajaran, pemeberian bimbingan terkait dengan permasalahan pengajaran yang dihadapi guru, melakukan penilaian terhadap bimbingan, pemberian saran terhadap guru terkait program pembelajaran, serta kepala sekolah membimbing guru melakukan penilaian terhadap hasil belajar siswa, dari proses bimbingan kepala sekolah dapat mencapai hasil yang maksimal dari etos kerja guru.

Nilai skor angket peran kepala sekolah sebagai konselorterdapat hal yang perlu ditingkatkan lagi oleh kepala sekolah seperti, merencanakan anggaran, mengadakan rapat anggaran dan mengadakan pelatihan penulisan karya ilmiah guna mencapai tujuan pendidikan.

Hasil penelitian ini juga dapat diperkuat oleh dasar teori menurut Aqib Zainal (2012:61), kepala sekolah, sebagai pengelola dan penguasa di sekolah, kepala sekolah otomatis menjabat sebagai pertanggung jawab terhadap pelaksanaan bimbingan dan konseling Kompetensi guru diharapkan dapat memberikan dampak positif bagi sekolah khususnya dalam proses pembelajaran di dalam kelas.

\section{SIMPULAN}

Hasil analisis data menunjukkan bahwa nilai $r_{x y}$ melebihiangka batas penolakan hipotesis nihil $\left(\mathrm{H}_{0}\right)$ yaitu $(0,279>0,510)$, hal ini berarti nilai $r_{x y}$ yang diperoleh dalam penelitian ini adalah "signifikan" dengan demikian hipotesis nihil $\left(\mathrm{H}_{0}\right)$ ditolak sedangkan hipotesis alternatif $\left(\mathrm{H}_{\mathrm{a}}\right)$ diterima, maka kesimpulan yang diperoleh dalam penelitian ini adalah: "Ada hubungan "Peran Kepala Sekolah Sebagai Konselor Dengan Etos Kerja Guru Di SMPN 6 Mataram Tahun Pelajaran 2017/2018". yang tergolong dalam kategori

Sedang.

\section{REFERENSI}

Arifin, Syamsul. Skrpsi. Hubungan Pelaksanaan Teknik Supervisi Kepala Sekolah Dengan Kompetensi Profesional Tenaga Pendidik Di SMAN 7mataram Tahun Pelajaran 2016/2017.SI :IKIP MATARAM

Aqib .2012. Bimbingan Dan Konseling Di Sekolah. Bandung:Yrama Widya.

Hasan, Basri. 2014. Kepemimpinan Kepala Sekolah. Bandung: CV. Pustaka Setia.

Khasanah, U. 2004. Etos Kerja: Sarana Menuju Puncak Prestasi. Harapan Utama. Yogyakarta.

Miftah, 2003. Kepemimpinan Dalam Manajemen, Jakarta: PT. Raja Grafindo.

Multahzam Ahmad.2005 Hubungan Kepemimpinan Demokratis Terhadap Etos Kerja Guru Di SMPN Islam AL-Badriyah Sundak Raring Tahun Pelajaran 2015/2016. Skripsi SI: IKIP Mataram.

Sari. 2016, Hubungan Antara Kemampuan Komunikasi Kepala Sekolah Dengan Etos Kerja Guru Di SMPN 3 Praya Timurtahun Ajaran 205/2016. Skripsi SI: IKIP Mataram.

Sugiyono. 2014. Metode Penelitian Kuantitatif, Kualitatif Dan R\&D. Bandung: Alfabeta. 
konseling, mengawasi pelaksanaan bimbingan dan konseling, menetapkan koordinator bimbingan dan konseling, menetapkan penugasan guru bimbingan dan konseling, menyiapkan surat pernyataan melakukan kegiatan bimbingan dan konseling, mengadakan kerjasama dengan instansi lain, dan melaksanakan kegiatan bimbingan dan konseling bagi kepala sekolah yang memiliki latar belakang pendidikan bimbingan dan konseling Prayitno ( Miftah, 2003)

Seorang yang mempunyai etos kerja banyak diungkapkan oleh para ahli, diantaranya seperti yang diungkapkan oleh Soewarso (Irda 2014: 343) menyatakan perilaku yang mencerminkan etos kerja meliputi: Efisiensi, kerajinan, keterampilan, sikap tekun, tepat waktu, kesederhanaan, kejujuran, sikap mengakui rasio dalam mengambil keputusan dan tindakan, kesediaan untuk berubah, kegesitan dalam menggunkan kesempatan-kesempatan yang muncul, sikap bekerja secara energois, sikap bersandar pada kekuatan sendiri, percaya diri, sikap mau bekerjasama, dan kesediaan mau memandang jauh kemasa depan.

Terindikasi di sekolah SMPN 6 Mataram etos kerja guru masih kurang baik, seperti kedisiplinan, kehadiran, dan ketepatan waktu guru pada saat masuk kelas untuk mengajar, sehingga dari etos kerja guru tersebut berdampak pada siswa dalam peningkatan belajar. disinilah peran kepala sekolah sebagai konselor terhadap guru yaitu mengkoordinasi, menyediakan dan melengkapi sarana dan prasarana yang diperlukan dalam kegiatan bimbingan pada guru. Begitupun peran guru kepada siswa sebagai konselor yaitu memberikan bimbingan belajar kepada semua siswa, bimbingan yang diberikan bertujuan untuk menemukan pribadi, mengenal lingkungan, dan merencanakan masa depan siswa, bimbingan berupaya untuk memberikan bantuan kepada peserta didik, bantuan ini berisfat psikologis agar siswa dapat melakukan penyesuaian diri, memperoleh perkembangan optimal dan kemandirian dan dalam memberikan bimbingan belajar, guru dapat bekerja sama dengan staf-staf sekolah.

Dari latar belakang di atas adapun masalah yang diangkat dari penuslisan ini yaitu Hubungan Peran Kepala Sekolah Sebagai Konselor Dengan Etos Kerja Guru di SMPN 6 MATARAM.

\section{KAJIAN LITERATUR}

Kedudukan konselor pada suatu lembaga pendidikan atau sekolah diperankan oleh kepala sekolah dan bisa juga diperankan oleh seorang guru yang mempunyai keahlian khusus atau metode khusus dalam menangani siswa yang bermasalah. Dalam kedudukannya sebagai konselor, kepala sekolah melakukan bimbingan dan pembinaan kepada para guru untuk meningkatkan kualitas kerjanya sebagai pendidik (Hasan, 2014: 145).

Menurut Sinamo (Multadzam, 2015: 17) etos kerja adalah konsep tentang kerja atau paradigma kerja yang diyakini oleh seseorang atau sekelompok orang sebagai sesuatu yang baik dan benar yang diwujudnyatakan melalui prilaku kerja mereka secara khas.Sinamo (Gunara 2005: 7) Mengemukakan etos kerja dapat diartikan sebagai suatu "Doktrin tentang kerja yang diyakini oleh seseorang atau sekelompok orang sebagai baik dan benar yang terwujud nyata secara khas dalam perilaku kerja mereka".

Bustaman Ismail (multadzam, 2015: 21) menyebutkanbeberapaciri-ciri orang yang memilikietoskerja yang tinggiantara 


\title{
HUBUNGAN PERAN KEPALA SEKOLAH SEBAGAI KONSELOR DENGAN ETOS KERJA GURU
}

\author{
Lu'luinNajwa ${ }^{1}$ dan Nita Ade Kalista ${ }^{2}$ \\ Prodi Administrasi Pendidikan, FIP IKIP Mataram \\ E-mail: lu'luinnajwa@ikipmataram.ac.id
}

\begin{abstract}
Abstrak: Etos kerja guru yang masih kurang baik terlihat dari kurangnya kedisiplinan, kehadiran, dan ketepatan waktu guru pada saat menjalankan tugasnya dan hal ini berdampak pada siswa. Tujuan penelitian ini adalah untuk mengetahui apakah ada hubungan peran kepala sekolah sebagai konselor dengan etos kerja guru di SMP Negeri 6 Mataram Tahun Pelajaran 2017/2018.Untuk mendapatkan data penelitian, penentuan subjek yang digunakan adalah teknik populasi.Teknik pengumpulan data menggunakan metode angket.Selanjutnya analisis data yang digunakan dalah metode analisis statistic dengan rumus Korelasi Product Moment. Berdasarkan hasil analisa data dalam penelitian ini, diperoleh nilai rhitung sebesar 0.510 , selanjutnya nilai tersebut dikonsultasikan dengan nilai rtabel product moment pada taraf signifikansi $5 \%$ dengan $\mathrm{N}=50$ diperoleh nilai sebesar 0.279 . Kenyataan tersebut menunjukkan bahwa rhitung lebih besar dari rtabel atau 0.510>0.279, maka hasil analisa data dalam penelitian ini dinyatakan signifikan. Hal ini berarti (H0) ditolak sedangkan (Ha) diterima. Kesimpulan yang diperoleh dalam penelitian ini adalah "Ada hubungan peran kepala sekolah sebagai konselor dengan etos kerja guru di SMP Negeri 6 Mataram Tahun Pelajaran $2017 / 2018$.
\end{abstract}

\section{Kata Kunci: Konselor, Etos Kerja}

\section{LATAR BELAKANG}

Keberhasilan program layanan

bimbingan dan konseling di sekolah tidak hanya ditentukan oleh keahlian dan keterampilan para petugas, namun juga sangat ditentukan oleh keterampilan seluruh staf sekolah, terutama dari kepala sekolah sebagai administrator dan supervisor. Sebagai administrator, kepala sekolah bertanggung jawab terhadap kelancaran pelaksanaan seluruh program sekolah, khususnya program layanan bimbingan dan konseling di sekolah yang dipimpinnya. Karena posisinya yang sentral, kepala sekolah adalah orang yang paling berpengaruh dalam pengembangan atau peningkatan pelayanan bimbingan dan konseling di sekolahnya. Sebagai supervisor, kepala sekolah bertanggung jawab dalam melaksanakan program-program penilaian, penelitian dan perbaikan atau peningkatan layanan bimbingan dan konseling, serta membantu mengembangkan kebijakan dan prosedur-prosedur bagi pelaksanaan program bimbingan dan konseling di sekolahnya.

Dalam kedudukannya sebagai konselor, kepala sekolah melakukan bimbingan dan pembinaan kepada para guru untuk meningkatkan kualitas kinerjanya sebagai pendidik. Selain itu kepala sekolah bertugas membimbing, mengajar, atau melatih para guru agar melakukan pelayanan bimbingan dan konseling kepada seluruh peserta didiknya demi meningkatkan prestasi dan moralitasnya ( Hasan, 2014: 143).

Kepala sekolah memiliki tugas dan fungsi terlaksananya kegiatan bimbingan dan konseling di sekolah. Secara rinci, tugas dan fungsi tersebut adalah mengkoordinasikan kegiatan pendidikan, menyediakan dan melengkapi sarana, melaksanakan program bimbingan dan 
Sugiyono. 2015. Metode Penelitian TIM IKIP Mataram. 2011. Pedoman Kuantitatif, Kualitatif Dan R\&D. Pembimbingan Dan Penulisan Karya Bandung: Alfabeta. Ilmiah.Mataram : IKIP Mataram. 